\title{
Abnormal calcium metabolism in normocalcaemic sarcoidosis
}

\author{
M REINER, G SIGURDSSON, V NUNZIATA, M A MALIK, G W POOLE, G F JOPLIN
}

\section{Patients and methods}

Thirteen consecutive patients (aged 23-53 years) with untreated sarcoidosis, diagnosed and followed-up at the chest clinic, Hammersmith Hospital, were included in this study when their general condition was being assessed. In 10 patients the diagnosis was supported by a positive biopsy finding or positive Kveim test, or both, while in the other three patients (cases 2,5, and 13) the diagnosis was made on clinical and radiological grounds. One patient (case 4) also had Paget's disease of the pelvis, so no data that might reflect his bone turnover will be shown.

Four patients were studied twice. The second time two patients were on steroid treatment; one (case 3) received prednisone $1 \mathrm{mg} /$ day, having been started on $20 \mathrm{mg} /$ day four months before, and the other (case 10) received prednisone $10 \mathrm{mg} /$ day. We also included the results of balance studies that had been carried out in two earlier patients. They had had histologically proved sarcoidosis and had been referred for investigation and treatment of hypercalcaemia. Their blood urea concentrations, as in the normocalcaemic series, were normal.

\section{CALCIUM ISOTOPE STUDIES}

Bone turnover was calculated by a "turnover-difference" method based on a single compartment model, ${ }^{14}$ using an intravenous injection of $10: \mathrm{Ci}$ of ${ }^{4} \mathrm{Ca}$. The results reported here are the exchangeable calcium pool size and the daily bone uptake rate of calcium. Both values were expressed in plasma units, which are units of volume corrected for body weight, ${ }^{15}$ and the uptake rate was also expressed in $\mathrm{mmol}$ calcium $/ \mathrm{kg}$ body weight $(2 \mathrm{mEq} / \mathrm{kg})$.

Absorption of ${ }^{45} \mathrm{Ca}$ was indexed by a double isotope method ${ }^{16}$ using simultaneous administration of $10 \mu \mathrm{Ci}$ of ${ }^{45} \mathrm{Ca}$ orally and $10 \mu \mathrm{Ci}$ of ${ }^{47} \mathrm{Ca}$ intravenously, the latter also being used for the above-mentioned kinetic studies. The results reflect the percentage of the oral tracer dose that has been absorbed. Our observed normal range, in 20 agematched normal volunteers was $32-65 \%$, with a mean of $49 \%$ (SD $11 \cdot 8)$.

Endogenous faecal calcium-that is, the unreabsorbed fraction of digestive juice calcium, was calculated from the amount of intravenously injected ${ }^{47} \mathrm{Ca}$ excreted in the faeces over six to nine days. ${ }^{17}{ }^{18}$ Our normal range, obtained from 11 normal subjects, gave a range of 3.4-5.45 mmol calcium/day. ${ }^{19}$ The calcium intake at home was estimated by diet history and using analytical food tables. ${ }^{20}$

\section{BALANCE STUDIES}

Calcium and nitrogen balances were carried out in the metabolic unit. ${ }^{21}$ Carmine red, but no inert faecal marker, was used. The validity of the three-day pooled faecal collection was checked by regularity of the nitrogen content.

\section{ANALYTICAL METHODS}

Serum and urinary calcium, inorganic phosphate, alkaline phosphatase, creatinine, and blood urea concentrations were measured in several samples in each patient by standard autoanalyser techniques. ${ }^{22}$ For the two balance studies, serum, urinary, and faecal calcium were estimated by flame spectrophotometry, the latter performed on a perchloric acid digest. ${ }^{22}$

\section{Results}

The biochemical data and the results of calcium absorption and kinetic studies are shown in the table. The serum calcium concentration was always within the normal range in all the patients except

Department of Medicine, King Edward Medical College, Lahore, Pakistan

M A MALIK, MRCP, associate professor 
Metabolic data. Normal ranges (mean $\pm 2 S D$ ) derived from 10 controls are given in parentheses in each column heading

\begin{tabular}{|c|c|c|c|c|c|c|c|c|c|c|c|c|c|}
\hline \multirow{3}{*}{$\begin{array}{l}\text { Case } \\
\text { No }\end{array}$} & \multicolumn{4}{|c|}{ Serum } & \multirow{3}{*}{$\begin{array}{c}\text { Blood } \\
\text { urea in } \\
\text { mmol } / 1 \\
(2 \cdot 5-7 \cdot 6)\end{array}$} & \multirow{3}{*}{$\begin{array}{l}\text { Urinary } \\
\text { calcium in } \\
\text { mmol/day } \\
(2 \cdot 5-7 \cdot 5)\end{array}$} & \multirow{3}{*}{$\begin{array}{c}\text { Phosphate } \\
\text { excretion } \\
\text { index } \\
( \pm 0.09)\end{array}$} & \multirow{3}{*}{$\begin{array}{c}\text { Absorption } \\
\text { of }{ }^{45} \mathrm{Ca} \\
(32-65)\end{array}$} & \multirow{3}{*}{$\underset{\begin{array}{c}\text { Calcium } \\
\text { intake } \\
(\mathrm{mmol} / \text { day })\end{array}}{ }$} & \multicolumn{4}{|c|}{${ }^{47} \mathrm{Ca}$ kinetic studies } \\
\hline & \multirow{2}{*}{$\underset{\text { in mmol } / 1}{\text { Calcium }}$} & \multirow{2}{*}{$\begin{array}{l}\text { Phosphorus } \\
\text { in mmol/1 } \\
(0 \cdot 66-1 \cdot 4)\end{array}$} & \multirow{2}{*}{$\begin{array}{c}\text { Alkaline } \\
\text { phosphatase } \\
\text { in KA } \\
\text { units } \\
(5-13)\end{array}$} & \multirow[b]{2}{*}{$\begin{array}{c}\text { Total } \\
\text { protein } \\
\text { in } g / 1 \\
(65-79)\end{array}$} & & & & & & \multirow[b]{2}{*}{$\begin{array}{c}\text { Pool size } \\
\text { in plasma } \\
\text { units } \\
(8-18)\end{array}$} & \multicolumn{2}{|c|}{ Bone uptake rate } & \multirow{2}{*}{$\begin{array}{c}\text { Endo- } \\
\text { genous } \\
\text { calcium in } \\
\text { mmol/day } \\
(2-5)\end{array}$} \\
\hline & & & & & & & & & & & $\begin{array}{c}\text { Plasma } \\
\text { units/day } \\
(0 \cdot 8-1 \cdot 6)\end{array}$ & $\begin{array}{c}\mathrm{mmol} / \\
\mathrm{kg} / \mathrm{day} \\
(0 \cdot 11-0 \cdot 20)\end{array}$ & \\
\hline $\begin{array}{l}1 \\
2 \\
3 \mathrm{a} \\
3 \mathrm{~b}^{*} \\
4 \mathrm{a} \\
4 \mathrm{~b} \\
5 \mathrm{a} \\
5 \mathrm{~b} \\
6 \\
7 \\
8 \\
9 \\
10 \mathrm{a} \\
10 \mathrm{~b}^{*} \\
11 \\
12 \\
13\end{array}$ & $\begin{array}{l}2.5 \\
2.6 \\
2.7 \\
2.7 \\
2 \cdot 75 \\
2.65 \\
2.65 \\
2 \cdot 6 \\
2.95 \\
2.5 \\
2.55 \\
2.5 \\
2.7 \\
2 \cdot 7 \\
2 \cdot 45 \\
2.7 \\
2.55\end{array}$ & $\begin{array}{l}1.4 \\
1.0 \\
1.1 \\
1.1 \\
1.3 \\
1.2 \\
1.3 \\
1.3 \\
1.2 \\
1.05 \\
1.3 \\
1.1 \\
0.8 \\
0.9 \\
1.0 \\
1.3 \\
1.2\end{array}$ & $\begin{array}{r}8 \\
10 \\
5 \\
5 \\
\\
\\
8 \\
7 \\
6 \\
13 \\
7 \\
9 \\
7 \\
6 \\
9 \\
6 \\
7\end{array}$ & $\begin{array}{l}71 \\
76 \\
78 \\
78 \\
84 \\
77 \\
73 \\
\\
69 \\
73 \\
74 \\
72 \\
66 \\
81 \\
74 \\
72 \\
81\end{array}$ & $\begin{array}{l}3 \cdot 5 \\
4 \cdot 0 \\
3 \cdot 0 \\
3 \cdot 7 \\
3 \cdot 7 \\
3 \cdot 5 \\
4 \cdot 5 \\
\\
3 \cdot 3 \\
4 \cdot 0 \\
3 \cdot 8 \\
4 \cdot 5 \\
4 \cdot 3 \\
4 \cdot 2 \\
4 \cdot 3\end{array}$ & $\begin{array}{c}2.65 \\
11 \cdot 3 \\
2 \cdot 75 \\
1 \cdot 3 \\
1 \cdot 15 \\
7 \cdot 8 \\
6 \cdot 45 \\
9 \cdot 5 \\
3 \cdot 9 \\
8 \cdot 0 \\
3 \cdot 1 \\
4 \cdot 65 \\
6 \cdot 1 \\
8 \cdot 4 \\
2 \cdot 25 \\
7 \cdot 5\end{array}$ & $\begin{array}{l}-0.04 \\
-0.03 \\
-0.05 \\
+0.01 \\
-0.06 \\
-0.03 \\
+0.04 \\
-0.08 \\
+0.01 \\
-0.01\end{array}$ & $\begin{array}{l}43 \\
76 \\
34 \\
30 \\
53 \\
67 \\
80 \\
56 \\
56 \\
42 \\
48 \\
68 \\
58 \\
69 \\
92 \\
77\end{array}$ & $\begin{array}{l}10 \cdot 5 \\
34 \cdot 5 \\
\\
52 \\
41 \cdot 5 \\
22 \\
22 \\
25\end{array}$ & $\begin{array}{l}17.0 \\
23.7 \\
13.5 \\
15.5 \\
11.2 \\
11.3 \\
12.4 \\
11.6 \\
12.2 \\
12.1 \\
12.2\end{array}$ & $\begin{array}{l}2 \cdot 6 \\
3.6 \\
1.1 \\
1.5 \\
1.0 \\
1.8 \\
2.3 \\
1.87 \\
1.8\end{array}$ & $\begin{array}{l}0.335 \\
0 \cdot 485 \\
0 \cdot 13 \\
0 \cdot 19 \\
0 \cdot 13 \\
0 \cdot 24 \\
0 \cdot 30 \\
0 \cdot 255 \\
0 \cdot 215\end{array}$ & $\begin{array}{l}4 \cdot 1 \\
4 \cdot 7 \\
3.85 \\
5 \cdot 0 \\
4.95 \\
1.95 \\
3.35 \\
2 \cdot 6 \\
3.85 \\
4 \cdot 75 \\
5.5 \\
5 \cdot 25 \\
2.7\end{array}$ \\
\hline
\end{tabular}

* On prednisone.

Conversion: SI to traditional units-Calcium: $1 \mathrm{mmol}=2 \mathrm{mEq}$. Phosphorus: $1 \mathrm{mmol}=3 \mathrm{mEq}$. Urea: $1 \mathrm{mmol} / 1 \approx 6 \mathrm{mg} / 100 \mathrm{ml}$.

two patients (cases 4 and 10) who had an isolated value of $2.8 \mathrm{mmol} / 1$ during their first study. The mean value for the 15 studies in 13 untreated patients was $2.6 \mathrm{mmol} / \mathrm{l}$. The serum inorganic phosphate and alkaline phosphatase concentrations were normal in all cases. Total serum protein concentration was normal in 10 and slightly raised in three patients. Blood urea concentration was normal in all cases as well as the serum creatinine in the nine patients in whom it was measured.

The urinary calcium output exceeded $7.5 \mathrm{mmol} /$ day in five patients.

The phosphate excretion index, ${ }^{23}$ which indirectly reflects parathyroid gland activity, was measured 17 times in nine patients. Although all values were normal they were all towards the lower limit of the normal range. In contrast the mean serum calcium levels for the same patients were in the upper half of the normal range.

Intestinal absorption of ${ }^{45} \mathrm{Ca}$, expressed as percentage absorption of the oral dose, was raised in six patients (fig 1). The mean value for the sarcoid group $(61.5 \%)$ was significantly higher than the mean $(49 \%)$ for the 20 controls $(P=0.02)$. Similar results were obtained when the individual daily calcium intake was taken into account by multiplying fractional absorption by intake. The urinary calcium output was proportional $(\mathrm{r}=0.70 ; \mathrm{P}<0.01)$ to absorption (fig 2$)$.

The isotopically determined bone uptake rate was raised in six of the 10 patients in whom it was measured; two also showed a raised exchangeable pool. Bone turnover correlated well with both the serum alkaline phosphatase levels $(r=0.62 ; \mathrm{P}<0.05)$ and with the ${ }^{45} \mathrm{Ca}$ absorption $(\mathrm{r}=0.80 ; \mathrm{P}<0.001)$ (figs 3 and 4). Bone turnover in turn correlated well $(r=0.65 ; P<0.05)$ with urine calcium values.

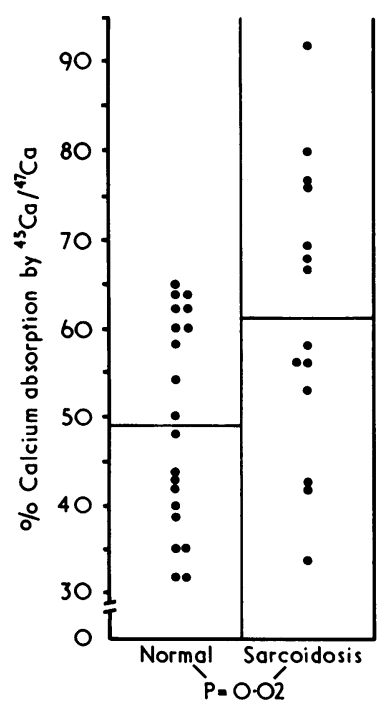

FIG 1-Calcium absorption values in patients with untreated sarcoidosis and normal subjects.

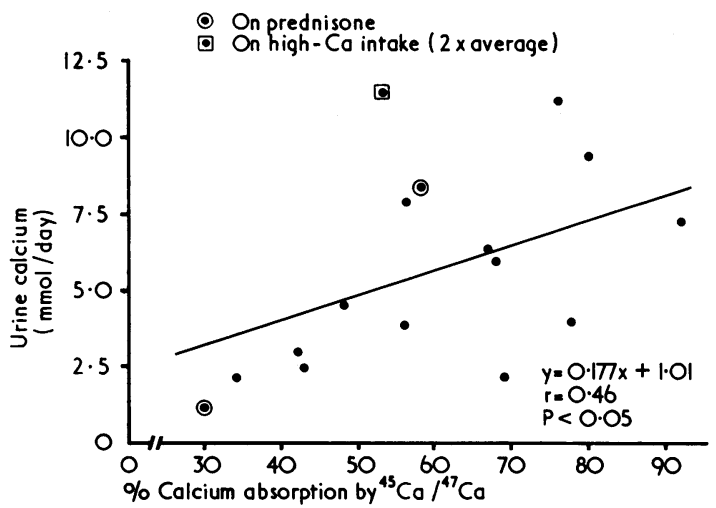

FIG 2-Relation of urine calcium excretion to calcium absorption. The two patients studied when taking prednisone were not included in regression analysis.

Conversion: SI to traditional units-Calcium: $1 \mathrm{mmol}=2$ $\mathrm{mEq}$.

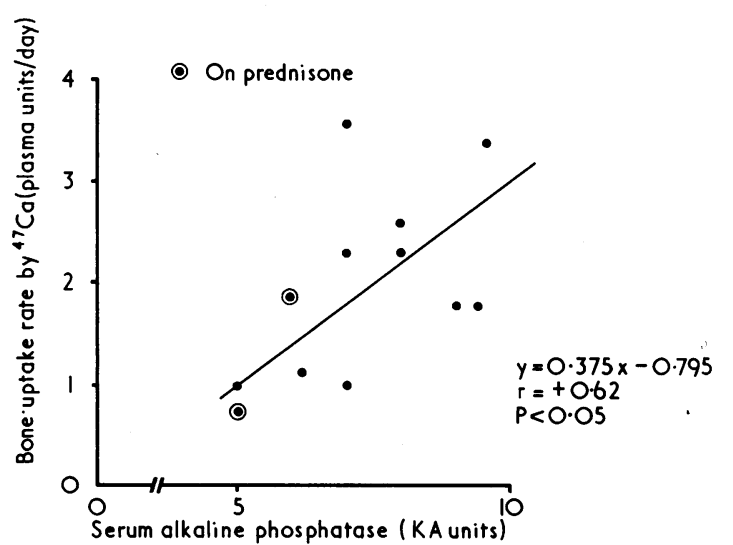

FIG 3-Relation of isotopically determined bone uptake rate and serum alkaline phosphatase. The two patients studied when taking prednisone were not included in regression analysis.

The endogenous faecal calcium output was essentially normal in this series.

The balance studies previously carried out in two patients with hypercalcaemic sarcoidosis and normal renal function both showed a negative calcium balance, which became even more negative under corticosteroid treatment (fig 5). This is typical of the findings in 16 out of 19 such studies we reviewed from nine published reports. 


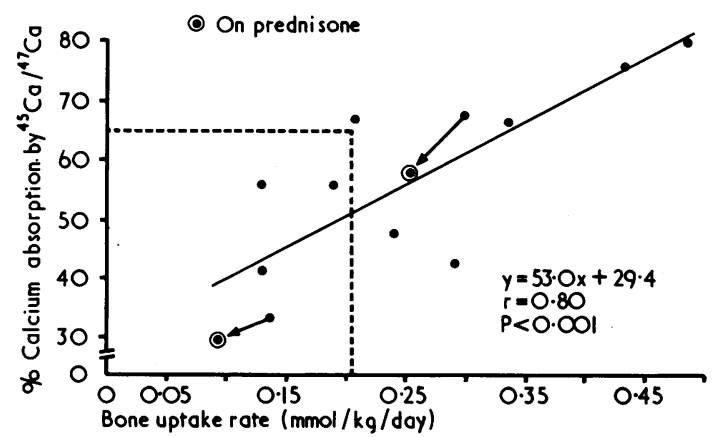

FIG 4-Relation of bone turnover and calcium absorption. Two patients studied when taking prednisone were not included in regression analysis.
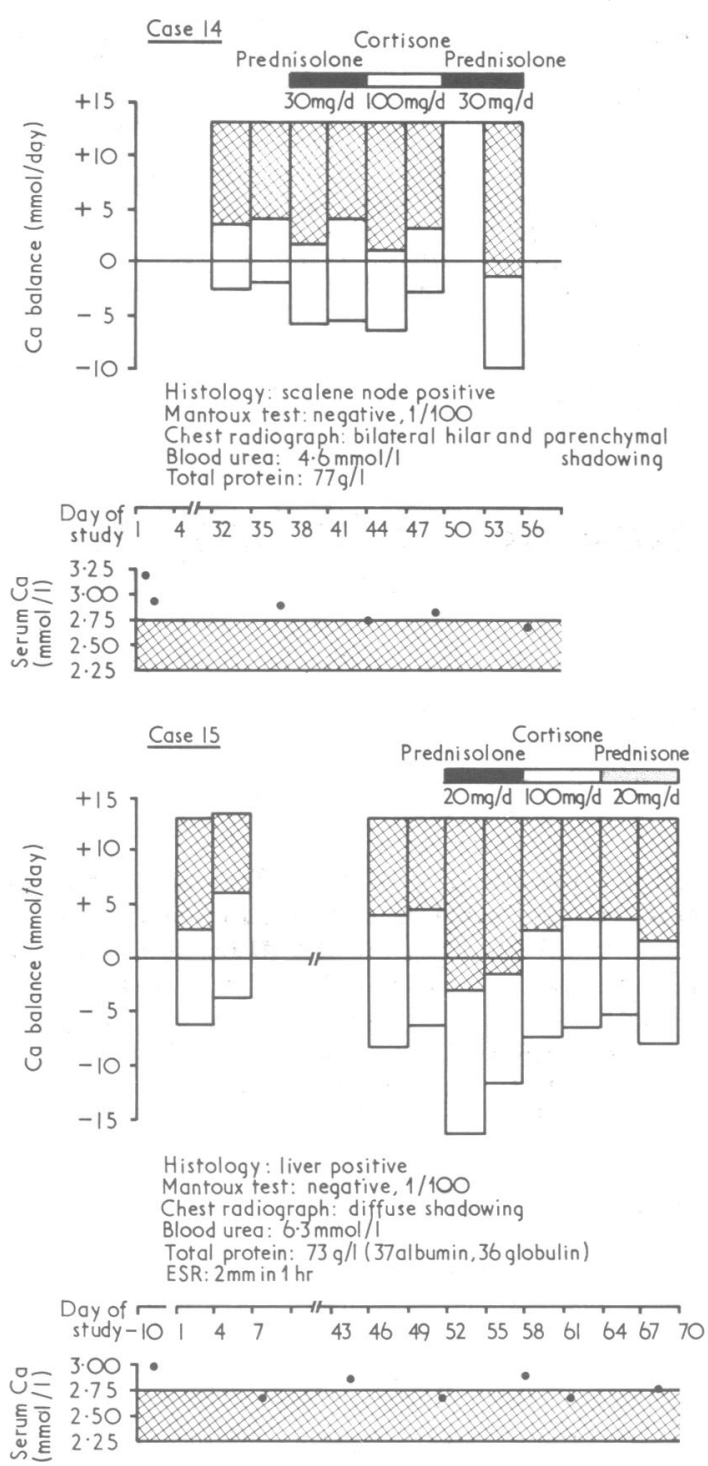

FIG 5-Calcium balances showing effect of corticosteroids in two previously studied hypercalcaemic patients (cases 14 and 15).

\section{Discussion}

This study shows that calcium metabolism is abnormal in some sarcoid patients, even when the serum calcium concentration is normal. Thus, hyperabsorption by the gut is often a feature in normocalcaemic sarcoidosis just as in hypercalcaemic sarcoidosis and may largely determine the urine output in patients on a normal calcium intake, as these are clearly correlated (fig 2). It has been speculated that the high net absorption so often reported in balance studies might be caused by a subnormal endogenous faecal calcium output, ${ }^{24}$ but neither we nor Miller et $a l^{13}$ found this. A clear tendency to increased bone turnover was shown by the calcium kinetic studies and supported by the correlation with the serum alkaline phosphatase concentration (fig 3). Presumably this is an effect on bone that is independent of the gut effect. But the fact that the gut and bone abnormalities were found to be proportional (fig 4), might mean that they are due to a common metabolic factor. The hypercalcuria may be a third effect of this factor, in correlating with both intestinal absorption $(r=0.70)$ and bone turnover $(r=0.65)$; it might also simply be a consequence of the increased renal calcium load.

No published reports have indicated the possible nature of the skeletal involvement leading to increased turnover, and there has been no systematic study of bone histology using quantitative techniques. It seems highly unlikely that the mechanism is bone destruction by sarcoid granulomata, because radiologically evident bone lesions and hypercalcaemia rarely coexist, ${ }^{25}{ }^{26}$ and no relation between these two aspects of the disease has been found. ${ }^{42-29}$ The fact that hypercalcaemia has been reported, ${ }^{6}$ even in the presence of a very low calcium intake, points to a substantial increase in skeletal resorption as the calcium source in such severely affected patients.

Parathyroid hormone does not seem to be responsible. The serum parathyroid hormone levels were found to be too low to measure by Cushard et $a l^{30}$ while we inferred a reduced biological effect of the hormone from the rather low phosphate excretion index values found. Lebacq ${ }^{31}$ reported similar findings. The fairly common finding of hypercalcuria in sarcoidosis ${ }^{32-34}$ would also be consistent with reduced parathyroid hormone action on the renal tubules.

An abnormality in vitamin $\mathrm{D}$ metabolism has long been suspected, ${ }^{2+35-37}$ but no evidence was found of excessive formation of either of the biologically active metabolites 25hydroxycholecalciferol, or 1, 25-dihydroxycholecalciferol. ${ }^{38}$ As the bioassayed antirachitic activity in the serum of hypercalcaemic sarcoid patients has been within the normal range, or even lower, ${ }^{89} 30$ the abnormality is probably located at the cellular level, presenting as a target organ hypersensitivity affecting the gut ${ }^{183640}$ and bone. ${ }^{912}$

A discriminative effect of corticosteroids on gut and bone ${ }^{9}$ explains the immediate rise in faecal calcium output and the delayed fall in urine calcium, the balance becoming transiently more negative (fig 5). The failure of hypercalcaemia in patients with sarcoidosis to respond to steroid treatment suggests coexistent hyperparathyroidism. ${ }^{41-44}$

Little has been reported about the natural history of the disturbance in calcium metabolism. In our series there seemed to be a positive correlation, within the first year, between duration of the disease and the severity of the effect on bone turnover. This is corroborated by the inverse correlation with the increase in the erythrocyte sedimentation rate, ${ }^{45}$ which is highest in the initial phase of the inflammatory process and progressively returns to normal within a few months.

The effect on bone seems to level off eventually (case 7). Similar conclusions can be drawn from the progressive fall of the total hydroxyproline excretion, which is raised in patients with short-lived disease but becomes normal in cases of longstanding sarcoidosis. ${ }^{46}$ Presumably the phase of increased bone resorption, as indicated by hydroxyproline excretion, is relatively short, and frank demineralisation of the skeleton is exceptional. ${ }^{478}$

Our general conclusion is that metabolic abnormalities are unexpectedly common in sarcoidosis. Presumably only the few patients who are most severely affected develop hypercalcaemia.

We thank the nurses and dietitians of the metabolic unit for their skilled help and Mrs B Leese for help with the isotope studies. MR was supported by a grant from the Swiss Academy of Medical Sciences, and GS by a grant from Sandoz Products Ltd. 
Clinical, radiological, and histological data on the patients may be obtained from a table deposited with the Librarian, Royal Society of Medicine, Wimpole Street, London W1.

Requests for reprints should be addressed to Dr M Reiner.

\section{References}

${ }^{1}$ Anderson, J, et al, Lancet, 1954, 2, 720.

${ }^{2}$ Henneman, P H, et al, fournal of Clinical Investigation, 1956, 35, 1229.

${ }^{3}$ McSwiney, R R, and Mills, I H, Lancet, 1956, 2, 862

4 Mather, G, British Medical fournal, 1957, 1, 248.

5 Scholz, D A, Fournal of the American Medical Association, 1959, 169, 682.

6 Jackson, W P U, and Dancaster, C, fournal of Clinical Endocrinology, 1959, $19,658$.

7 Parfitt, A M, et al, Clinical Science, 1964, 27, 463.

${ }^{8}$ Bell, N H, and Bartter, F C, Annals of Internal Medicine, 1964, 61, 702.

9 Bell, N H, and Bartter, F C, Acta Endocrinologica, 1967, 54, 173.

10 Goldstein, R A, et al, American fournal of Medicine, 1971, 51, 21.

11 Hunt, B J, and Yendt, E R, Annals of Internal Medicine, 1963, 59, 554

12 Hendrix, J Z, Annals of Internal Medicine, 1966, 64, 797.

13 Miller, B, et al, in Proceedings of the Vth International Conference on Sarcoidosis, Prague, p 319. Praha, Universita Karlova, 1969.

14 North, K, et al, Medical uses of $\mathrm{Ca}^{47}$, Technical Report Series No 10. Vienna, International Atomic Energy Agency, 1962.

15 Fraser, R, et al, Quarterly Fournal of Medicine, 1960, 29, 85.

16 Reiner, M, et al, Calcified Tissue Research, 1970, 4, 95.

17 Bronner, F, Nutritio et Dieta, 1962, 3, 22.

18 Heaney, R P, and Skillman, T G, fournal of Laboratory and Clinical Medicine, 1964, 64, 29.

19 Melvin, K E W, et al, Quarterly fournal of Medicine, 1970, 39, 83.

${ }^{20}$ McCance, R A, and Widdowson, E M, The Composition of Foods. London, HMSO, 1960.
21 Reifenstein, E C, et al, fournal of Clinical Endocrinology, 1945, 5, 367.

22 Wootton, I D P, Microanalysis in Medical Biochemistry, 4th edn, London Churchill, 1964.

${ }^{23}$ Nordin, B E C, and Fraser, R, Lancet, 1960, 2, 947.

24 Winnacker, J L, et al, New England fournal of Medicine, 1968, 278, 427.

${ }^{25}$ Harrell, G T, and Fisher, S, fournal of Clinical Investigation, 1939, 18, 687.

${ }^{26}$ Davidson, C N, et al, Radiology, 1954, 62, 203.

27 Holt, J F, and Owens, W I, Radiology, 1949, 53, 11.

${ }^{28}$ Longcope, W T, and Freiman, D G, Medicine, 1952, 31, 1.

${ }^{29}$ Gendel, B R, et al, American fournal of Medicine, 1952, 12, 205.

30 Cushard, W G, jun, et al, New England fournal of Medicine, 1972, 286, 395.

31 Lebacq, E, et al, Postgraduate Medical fournal, 1970, 46, 526.

32 James, D G, Acta Medica Scandinavica, 1964, 176, Suppl No 425, p 203.

${ }^{33}$ Basset, G, Bulletins et Mémoires de la Société Médicale des Hôpitaux de Paris, 1964, 115, 583.

34 Turiaf, J, and Battesti, J P, Revue de la Tuberculose et de Pneumologie, $1971,35,569$.

${ }^{35}$ Scadding, J G, British Medical fournal, 1950, 1, 745.

36 Taylor, R L, et al, American fournal of Medicine, 1963, 34, 221.

37 Dent, C E, Postgraduate Medical fournal, 1970, 46, 471.

${ }^{38}$ Mawer, E B, et al, Nature, New Biology, 1971, 232, 188

${ }^{39}$ Thomas, W C, jun, fournal of Clinical Investigation, 1959, 38, 1078.

${ }^{40}$ Bell, N H, et al, American fournal of Medicine, 1964, 36, 500.

${ }^{41}$ Dent, C E, and Watson, L, British Medical fournal, 1966, 1, 646.

42 Pedersen, K O, Acta Medica Scandinavica, 1967, 182, 781.

43 Winnacker, J L, et al, American Fournal of Medicine, 1969, 46, 305.

${ }^{44}$ Bohnen, R F, et al, fournal of the American Medical Association, 1971, 217, 1385.

45 Reiner, M, et al, Proceedings of the Ninth European Symposium on Calcified Tissues, p 91. Vienna, Facta-Publication, 1973.

46 Massare, D, et al, American Review of Respiratory Disease, 1966, 93, 929.

47 Van Creveld, S, Annales de Pediatrie, 1941, 157, 1.

${ }^{48}$ Klatskin, G, and Gordon, M, American fournal of Medicine, 1953, 15, 484.

\title{
Mild hypertension: a clinical trial conducted in hospital and general practice
}

\author{
H E JOESBURY, \\ C A PHILLIPS, \\ R T GARRETT, \\ E WILKES, A J SMITH
}

British Medical fournal, 1976, 2, 1476-1479

\begin{abstract}
Summary
To compare findings in a hospital trial of hypotensive drugs with those in a general practice trial several patients with mild hypertension were studied at the same time in hospital and in general practice. They received bendrofluazide and potassium chloride or bendrofluazide, potassium chloride, and reserpine according to a double-blind crossover protocol, and blood biochemical values were studied over eight weeks and six months. When reserpine was withdrawn from nine women they followed a modified protocol comparing bendrofluazide and potassium chloride with potassium chloride alone.
\end{abstract}

Department of Community Care and General Practice, University of Sheffield, Sheffield

H E JOESBURY, MB, MRCGP, general practitioner research assistant

E. WILKES, FRCP, FRCGP, professor

Glaxo Laboratories Ltd, Greenford, Middlesex

R T GARRETT, MPs, clinical trials associate

Department of Pharmacology and Therapeutics, University of Sheffield, Sheffield S6 3DA

C A PHILLIPS, BSC, research technician

A J SMITH, DM, FRCP, consultant physician and associate in medicine
The blood pressure values measured by the general practitioners were similar to those measured in hospital. Both the diuretic alone and the diuretic with reserpine produced significant falls in blood pressures. Although plasma renin activity increased on diuretic treatment, continued treatment did not produce a further increase, and levels gradually declined towards normal.

\section{Introduction}

Clinical trials of antihypertensive drugs are usually carried out in hospitals, where strict control of conditions can be ensured. Difficulty in recruiting enough patients in hospital and a feeling that less artificiality attaches to studies conducted away from the wards or outpatient clinics have led recently to many more trials being performed exclusively in general practice. ${ }^{12}$ So far as we know no comparison has ever been made of results obtained in the same patient population studied at the same time both in general practice and the hospital clinic. This doubleblind crossover study was designed to provide such a comparison using well-established treatment for mild hypertension.

In most clinical trials short-term changes in the patients' blood chemistry are reported, from which long-term conclusions are sometimes drawn. As a secondary objective in this study we have examined and compared the changes in chemical values in the plasma (including plasma renin activity (PRA)) over both short (eight weeks) and longer periods (six months) of treatment. 